\title{
Harpagifer bispinis, Magellan Plunderfish
}

\author{
Assessment by: Buratti, C., Díaz de Astarloa, J., Hüne, M., Irigoyen, A., Landaeta, \\ M., Riestra, C. \& Vieira, J.P.
}

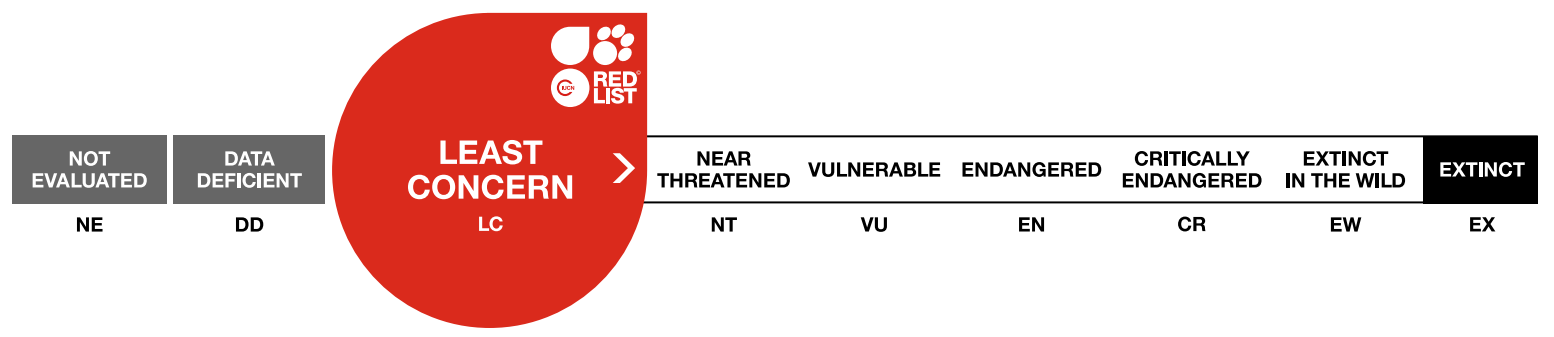

View on www.iucnredlist.org

Citation: Buratti, C., Díaz de Astarloa, J., Hüne, M., Irigoyen, A., Landaeta, M., Riestra, C. \& Vieira, J.P. 2020. Harpagifer bispinis. The IUCN Red List of Threatened Species 2020:

e.T159100515A159406918. https://dx.doi.org/10.2305/IUCN.UK.2020-

3.RLTS.T159100515A159406918.en

Copyright: (C) 2020 International Union for Conservation of Nature and Natural Resources

Reproduction of this publication for educational or other non-commercial purposes is authorized without prior written permission from the copyright holder provided the source is fully acknowledged.

Reproduction of this publication for resale, reposting or other commercial purposes is prohibited without prior written permission from the copyright holder. For further details see Terms of Use.

The IUCN Red List of Threatened Species ${ }^{T M}$ is produced and managed by the IUCN Global Species Programme, the IUCN Species Survival Commission (SSC) and The IUCN Red List Partnership. The IUCN Red List Partners are: Arizona State University; BirdLife International; Botanic Gardens Conservation International; Conservation International; NatureServe; Royal Botanic Gardens, Kew; Sapienza University of Rome; Texas A\&M University; and Zoological Society of London. 


\section{Taxonomy}

\begin{tabular}{|c|c|c|c|c|}
\hline Kingdom & Phylum & Class & Order & Family \\
\hline Animalia & Chordata & Actinopterygii & Perciformes & Harpagiferidae \\
\hline
\end{tabular}

Scientific Name: Harpagifer bispinis (Forster, 1801)

\section{Synonym(s):}

- Batrachus bispinis Forster, 1801

\section{Common Name(s):}

- English:

Magellan Plunderfish

\section{Taxonomic Source(s):}

Fricke, R., Eschmeyer, W.N. and Van der Laan, R. (eds). 2019. Eschmeyer's Catalog of Fishes: genera, species, references. Updated 03 September 2019. Available at: http://researcharchive.calacademy.org/research/ichthyology/catalog/fishcatmain.asp.

\section{Taxonomic Notes:}

Work is underway that will consider Harpagifer palliolatus a synonym of $H$. bispinis (M. Hüne pers. comm. 2019).

\section{Assessment Information}

Red List Category \& Criteria: Least Concern ver 3.1

Year Published: 2020

Date Assessed: December 5, 2019

\section{Justification:}

This rocky, intertidal species has a relatively small range, but is common and abundant. There are no known major threats at this time; therefore, it is listed as Least Concern.

\section{Geographic Range}

\section{Range Description:}

This species is endemic to the Patagonia Sea region. It occurs in the southeastern Pacific off Chile from the Gulf of Penas at $47^{\circ} \mathrm{S}$ to the Magellan Strait and Cape Horn into the southwestern Atlantic to the Deseado River in Argentina. The depth range is 0-50 metres. As Harpagifer palliolatus is expected to be synonymized under $\mathrm{H}$. bispinis, the Malvinas Islands would then be added to this distribution. Records from the Antarctic Peninsula should be attributed to Harpagifer antarcticus (Hüne et al. 2015).

\section{Country Occurrence:}

Native, Extant (resident): Argentina; Chile

\section{FAO Marine Fishing Areas:}


Native: Atlantic - southwest

Native: Pacific - southeast 


\section{Distribution Map}

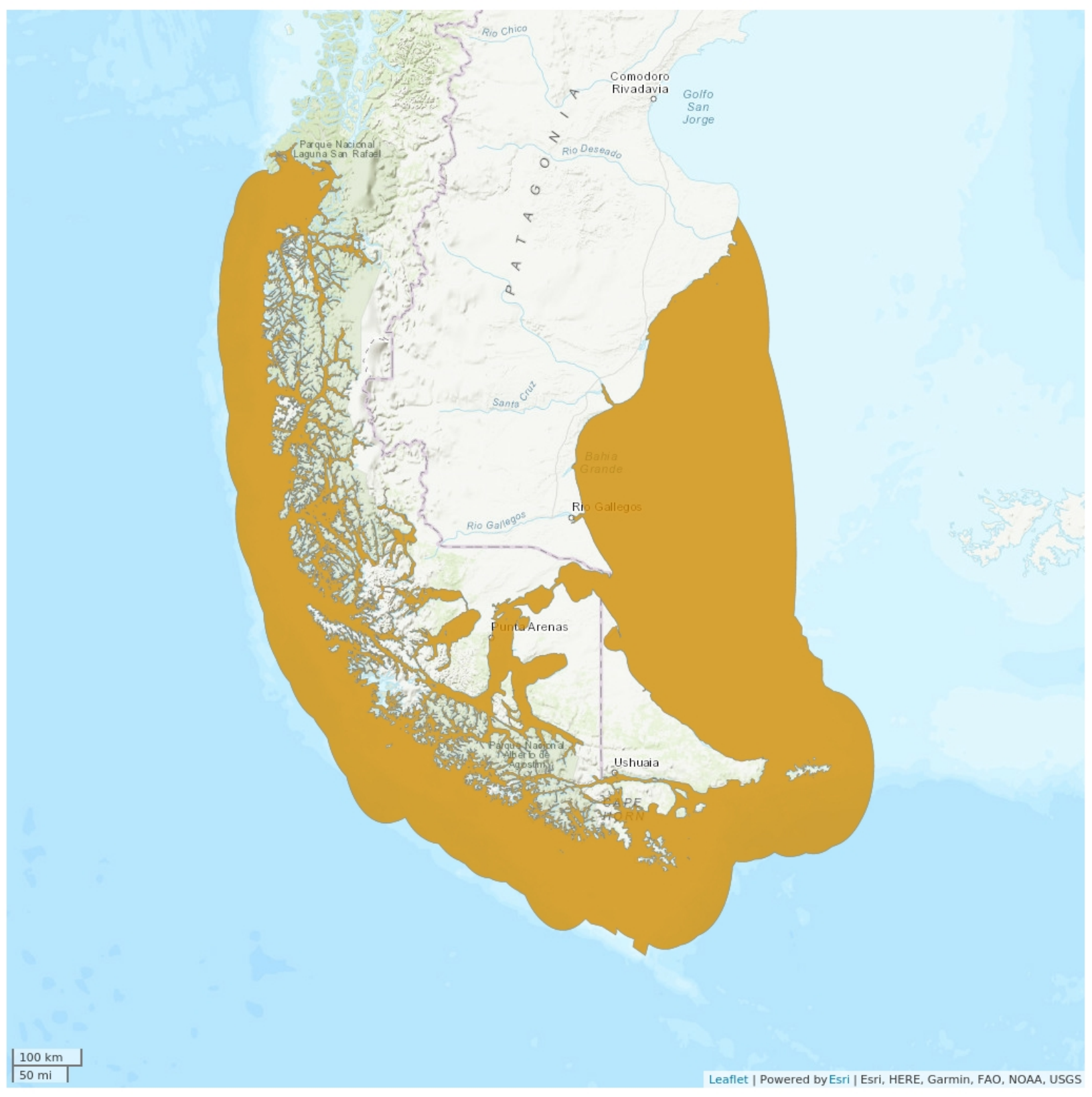

Legend

EXTANT (RESIDENT)
Compiled by:

IUCN Marine Biodiversity Unit/GMSA 2020

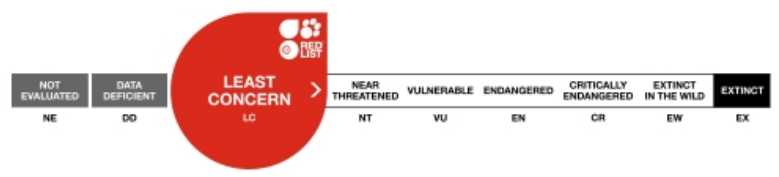

\section{8: G Gist}

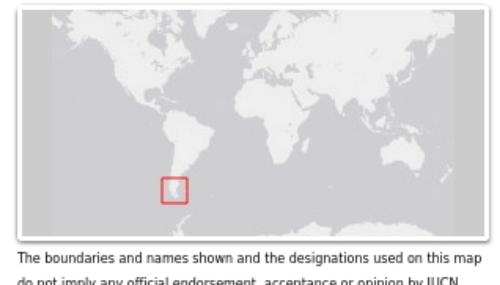




\section{Population}

This species is abundant in the intertidal areas of fjords and channels in Patagonia (Hüne and Vega 2016). Despite it being one of the most abundant species, its larvae are not abundant and account for less than $0.03 \%$ of larval abundance (M. Hüne and M. Landaeta pers. comm. 2019).

Current Population Trend: Unknown

\section{Habitat and Ecology (see Appendix for additional information)}

This demersal species occurs in the intertidal zone on rocky substrate. This habitat is increasing due to the melt of glaciers in the intertidal zone (M. Hüne pers. comm. 2019). The maximum total length is 10 $\mathrm{cm}$, but most individuals are less than $7 \mathrm{~cm}$. It has an ecological role as an important prey item for sea birds and penguins (Hüne and Vega 2016).

Systems: Marine

\section{Use and Trade (see Appendix for additional information)}

This species is not utilized and does not occur as bycatch in fisheries.

\section{Threats}

This species may be consumed by the invasive Chinook Salmon (Oncorhynchus tschawytscha), but this is not expected to be driving global-level population declines approaching a Near Threatened or threatened level at this time.

\section{Conservation Actions}

There are no species-specific conservation measures.

\section{Credits}

Assessor(s): $\quad$ Buratti, C., Díaz de Astarloa, J., Hüne, M., Irigoyen, A., Landaeta, M., Riestra, C. \& Vieira, J.P.

Reviewer(s): $\quad$ Linardich, C.

Contributor(s): $\quad$ Campagna, C.

Facilitator(s) and Falabella, V., Linardich, C. \& Wildlife Conservation Society

Compiler(s): 


\section{Bibliography}

Hüne, M. and Vega, R. 2016. Feeding habits in two sympatric species of Notothenioidei, Patagonotothen cornucola and Harpagifer bispinis, in the Chilean Patagonian channels and fjords. Polar Biology 39(12): 2253-2262.

Hüne, M., González-Wevar, C., Poulin, E., Mansilla, A., Fernández, D.A. and Barrera-Oro, E. 2015. Low level of genetic divergence between Harpagifer fish species (Perciformes: Notothenioidei) suggests a Quaternary colonization of Patagonia from the Antarctic Peninsula. Polar Biology 38(5): 607-617.

IUCN. 2020. The IUCN Red List of Threatened Species. Version 2020-3. Available at: www.iucnredlist.org. (Accessed: 10 December 2020).

\section{Citation}

Buratti, C., Díaz de Astarloa, J., Hüne, M., Irigoyen, A., Landaeta, M., Riestra, C. \& Vieira, J.P. 2020.

Harpagifer bispinis. The IUCN Red List of Threatened Species 2020: e.T159100515A159406918.

https://dx.doi.org/10.2305/IUCN.UK.2020-3.RLTS.T159100515A159406918.en

\section{Disclaimer}

To make use of this information, please check the Terms of Use.

\section{External Resources}

For Supplementary Material, and for Images and External Links to Additional Information, please see the Red List website. 


\title{
Appendix
}

\section{Habitats}

(http://www.iucnredlist.org/technical-documents/classification-schemes)

\begin{tabular}{|c|c|c|c|}
\hline Habitat & Season & Suitability & $\begin{array}{l}\text { Major } \\
\text { Importance? }\end{array}$ \\
\hline 9. Marine Neritic -> 9.2. Marine Neritic - Subtidal Rock and Rocky Reefs & Resident & Suitable & Yes \\
\hline 12. Marine Intertidal -> 12.1. Marine Intertidal - Rocky Shoreline & Resident & Suitable & Yes \\
\hline
\end{tabular}

\section{Additional Data Fields}

\author{
Distribution \\ Lower depth limit (m): 50 \\ Upper depth limit (m): 0
}




\section{The IUCN Red List Partnership}

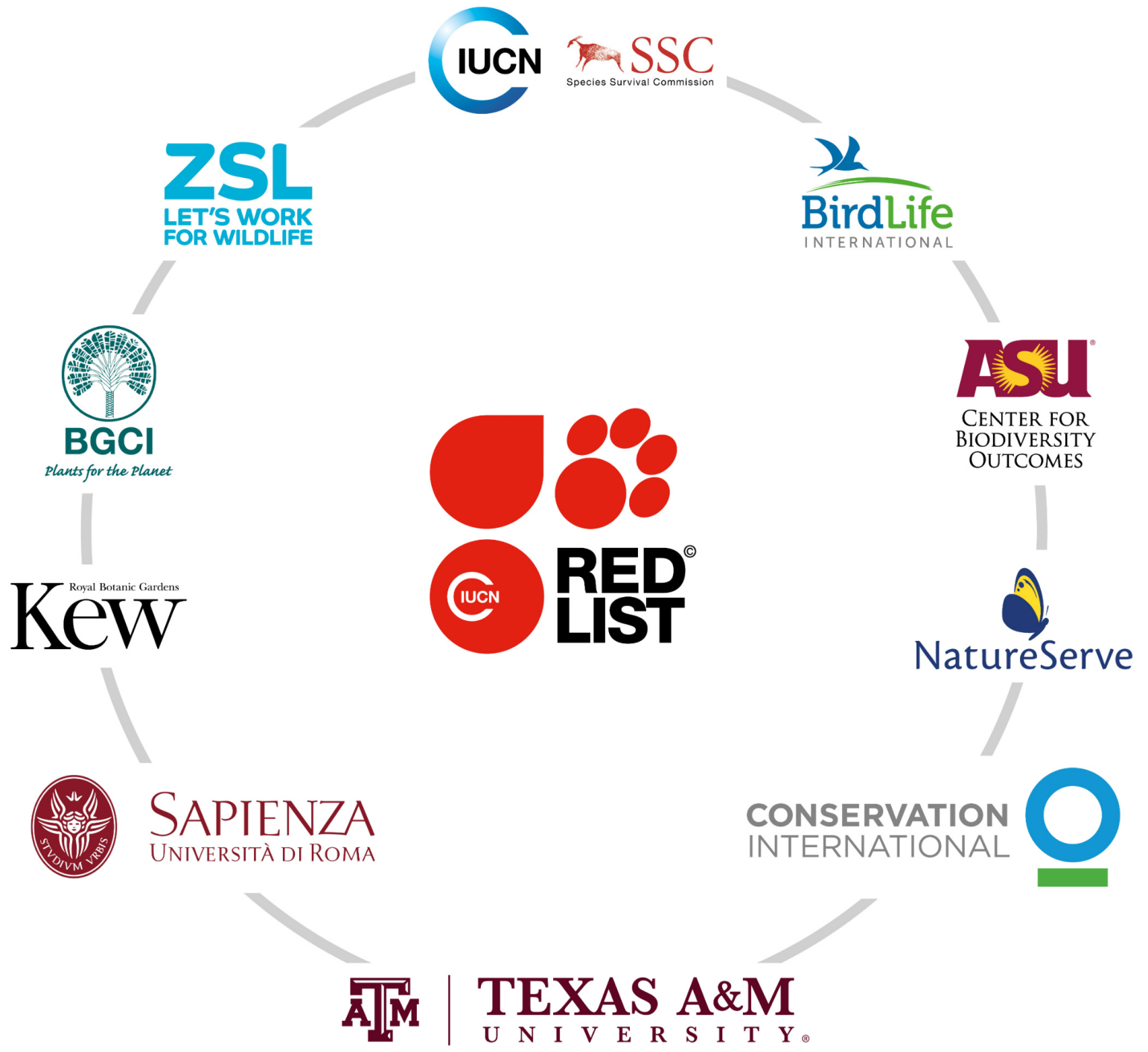

The IUCN Red List of Threatened Species ${ }^{\mathrm{TM}}$ is produced and managed by the IUCN Global Species Programme, the IUCN Species Survival Commission (SSC) and The IUCN Red List Partnership.

The IUCN Red List Partners are: Arizona State University; BirdLife International; Botanic Gardens Conservation International; Conservation International; NatureServe; Roval Botanic Gardens, Kew; Sapienza University of Rome; Texas A\&M University; and Zoological Society of London. 